ptom was rectal di-comfort after urination. A litile later there was pain over the pubes, and in the left hypogast, it and iliac reginns. Then came a muco-ranguirenus stool, after which the symptoms subsided for several months.

In one of Mr. Bryant's cases ${ }^{5}$ the symptoms began three months before the patient came under treatment, with diarrhœa, tenesmus, and muco-sanguineous stools. Then there was an interval of great improvement, after which unmistakable sigus of the disease set in. In another of his cases the first symptom noticed was the passage of wind by the urethra, and for more than two years there was no other symptom.

In the case which I have recorded there was no history of these early symptoms. The only really valuable diagnostic sign was the mixture of urine with the freces. The opening being tolerably high up, the urine was probably retaineil some time before its expulsion, when it was intimately mixed with the bowel contents. Thus the admixture attracted neither the attention of the patient nor of his atteudants, though it had probably existed for a considerable perior. In illustration of this point, Mr. Charles Hawkins's case ${ }^{6}$ is highly interesting. In consequence of a communication between the bladder and sigmoid flexure, the rectum bad undergone great dilatation, acting as a second bladder, the urine accumulating there, and being dustharged in large quantities at a time per anum.

In conclusion, I wish to offer a remark on the dreadful burning and scalding pain which was for some time the most prominent symptom in this case. It will be remarked that a similar pain almost always occurs in the last stage of malignant disease of the bladder. In the earlier stages it is absent. In several cases, in which this pxin bas been very marked, I have found extensive ulceration of the vesical mucous membrane; and I am inclined to believe that it is to be attributed to this lesion.

Enfield, Middlesex.

\section{A CASE OF POISONING WITH BELLADONNA.} By PROTHEROE SMITH, M.D.

ON September 1st, 1881, Mrs. K- a bighly nervous patient, suffering from chronic metritis, inadveitently swallowed from half an ounce to an ounce of belladonna liniment, equivalent to about half an ounce of the root, about 5 or 6 A.M., just before which her bowels had acted copiously. She was seen by her attendant between 9 and 10 A.M., who administered a mustard emetic, which caused her to vomit freely. I first visited her at 2 P.M., when she was insensible, with wild, scared, and pinched features, anæmic, with lips blue and pale, the pupils being fully dilated, and not acting to the light; her tongue was rough and dry ; the pulse was 130 , threddy and intermittent; the heart's action feeble, especially the first sound; respiration 30 in the minnte; temperature normal. When roused she was quite incoherent: pain in the pit of the stomach, calling out when it was pressed; frequent retching; large quantities of light-coloured urine have been passed unconsciously. I prescribed one drachm of aromatic spirit of ammonia with four minims of sedative solution of opinm (the only suitable remedes at hand), and arrowront or beef-tea and brandy every ten or fifteen miuutes. At 4.15 P. M. she looked better, more colour in her cheeks and lips, which continue pale, but piuk. She has taken the food ordered every ten minutes ; sickness less ; pulse 112 , fuller, without intermission; respiration 28; pupils remain dilated. She is still incoherent, but is able to retain her urine.

Sept. 2nd.-11 A.M : Has passed a very restless night, and is still incoherent, imagining she has conumitted murder, \&u Pulse faller, wirhont incermission; heart's first stund louder, still rbythm imperfect; tongue somewhat moister excessive itching of the nares. Cheeks flushed, lips red; the fingers and nails, which at first were blue, are more natural in colour. Abdominal pains miliuated; when roused says she hears everybody as though at a great distance, and sees them as greatly magnified; talks rapidly and incoherently. Catamenia appeared this morning befure due. Ordered half a drachm of hydrate of chloral, with one ounte of water every four hours, with twenty minims of aromatic

5 Transactions of the Clinical Society (1872), p. 127, et seq

6 Transactions of the Medical and Chirurgical Society, vol. xli., p. 441 spirt of ammonia. -5.45 P. Soon after taking the chloral she became rational. P'upils act better. P'ulse 80 , and full witbout irregnlarity ; says she has not slept siuce whe took the poison. To take forty minims of chloral, ten minims of nepenthe with water at bed time, and, if necessary, repeat every six hours.

Sept. 3rd, 11 A.m.: Says the medicine (chloral) has acted like magic, the first dose restoring her senses in half an hour. She has slept all night, and is now restored to her usual bright and intelligent expression, and is quite herself again.

In the above instauce it is worthy of remark that the domestic remedies generally at hand-viz, mustard emetic, sal volatile, brandy, and opium-so far modified the urgent symptoms as to render the case less dangerous to life, and gave time for procuring more efficient remedies; that the extreme feebleness and irregularity of pulse were at once relieved by small doses of liquid food, brandy, ammonia, and opium, but that for several hours it was found nece-sary to exhibit them at first every ten minutes, and afterwards every fifteen or twenty, in order to sustain the heart's action and prevent its intermitting. But the remedy which of all others produced the most happy result, restoring quickly the normal action of the heart and iris, and effecting a rapid cure, was the hydrate of chloral in half-drachm doses, with a small quantity of snlution of opium, \&c., every four to six hours, and a larger dose at night.

A case of poisoniug by belladonna is reported in THE LANcET of Jdnuary $8 \mathrm{th}$, 1881, suggested by Dr. Trocquart of Borleaux, in which chloral hydiate was successfully employed as an enema.

Another case is wuhlished by N. Grattan, L.R.C.P. Ed. in the British Mectical Journal of April 16th, 1881, in which one-fifth of a grain of pilocarpin was hypodermically injected every fifteen minutes, with equally favourable results. As, however, the chloral is shown to be such an efficient autidote, I should be di-posed in cases of poisoning with belladonna always to prefer it to the new and powerful remedy of pilocarpin, which in unskilled hands might not be altogether exempt from risk.

Park-street, Grosvenor-square.

\section{9 解litrol}

\section{HOSPITAL PRACTICE, BRITISH AND FOREIGN.}

Nolla autem est alia pro certo noscendi via, nisi quamplurimas et morborum et dissectionum historias, tum aliorum tum proprias collectas habere, et inter se comparare.-MongAGN De Sed. et Caus. Morb., lib. iv. Procmium.

\section{WEST LONDON HOSPITAL.}

STONE IS THE BLADDER; BIGELOW'S OPERATION ; CURE.

(Under the care of Mr. TEEVAN.)

SAMUEL A-, fifty-nine years old, watchmaker, was admitted on the 29 th of August, having been referred to Mr. Teevan's care by Dr. Pearse. From notes taken by the house-surgeon, Mr. Lloyd, it appeared that one year before the patient began to be troubled with frequent and painful micturition. Some months later blood commenced to escape in drops at the close of the act of urination, and he was unable to ride in an omnibus on account of the pain he experienced. So long as he was quiet in bed he did not suffer much, but directly he walked about he had frequently to make water, attended by much pain. About two years before admission he had a long and severe attack of rheu. matic fever, and affer he recorered he noticed that if he walked quickly, or upstairs, his breathing became much embarrased. The patient was a very stout man, measuring one yard and a half round the waist. He and his father were born in London, but his mother was a uative of Kent. The urine was acid, its sp. gr. 1020, and there was a deposit which containel albumen.

On August 30th the man was put under the influence of ether by Mr. 'T. G. Alderton. Mr. 'Teevan iutroduced a medium-sized flat-bladed lithorrite, and seized a stone about one inch in diameter. Having broken it to pieces he evacuated the fragments with a No. 27 tube. The patient was 